\title{
PENDIDIKAN KARAKTER KRISTEN SEBAGAI UPAYA MENGEMBANGKAN SIKAP BATIN PESERTA DIDIK
}

\author{
Anton Nainggolan*1 \\ ${ }^{1}$ Sekolah Tinggi Teologi Kadesi \\ *antonnainggolan@gmail.com
}

\begin{abstract}
Successful education is education that can shape human behavior, not just equip people with knowledge and information. Research Objectives: (1). What is the meaning of Christian character education? (2). What is the role of Christian character education in the development of the inner attitudes of students? (3). What Are the Natural Implications of Human Total Disability? Methods: This research was conducted using a qualitative method with a literature study approach. Research Results: (1). Education that shapes and develops the inner attitude of students so that they are able to behave and behave wisely, and be responsible in their daily lives as Christians (2). Character education plays an important role in the personal formation of students. In the process various noble morals are discussed, including honesty, virtue, courage, discipline, generosity, tolerance, and responsibility. (3). Proper character education must actually begin with a personal encounter with Jesus. Character education and learning are tools, media or means in the formation of the human person.
\end{abstract}

Keywords: Education, Character, Noble Morals, Encounter, Jesus, Holy Spirit, Belief.

\begin{abstract}
Abstrak
Pendidikan yang berhasil adalah pendidikan yang dapat membentuk perilaku manusia, bukan sekedar membekali manusia dengan pengetahuan dan informasi saja. Tujuan Penelitian: (1). Apakah pengertian pendidikan karakter Kristen? (2). Bagaimanakah peran pendidikan karakter kristen terhadap pengembangan sikap batin peserta didik? (3). Bagaimanakah Implikasi Natur Ketidakmampuan Total Manusia? Metode: Penelitian ini dilakukan dengan metode Kualitatif dengan pendekatan studi pustaka. Hasil Penelitian: (1). Pendidikan yang membentuk dan mengembangkan sikap batin peserta didik supaya mampu bersikap dan berperilaku bijak, serta bertanggung jawab dalam kehidupannya sehari-hari sebagai orang Kristen (2). Pendidikan karakter berperan penting dalam pembentukan pribadi peserta didik. Dalam proses itu berbagai akhlak luhur diperbincangkan, termasuk kejujuran, kebajikan, keberanian, kedisiplinan, kemurahan, toleransi, tanggung jawab. (3). Pendidikan karakter yang tepat sebenarnya harus dimulai dengan perjumpaan pribadi dengan Yesus. Pendidikan dan pembelajaran karakter merupakan alat bantu, media atau sarana dalam pembentukan pribadi manusia.
\end{abstract}

Kata kunci : Pendidikan, Karakter, Akhlak mulia, Perjumpaan, Yesus, Roh Kudus, Percaya. 


\section{PENDAHULUAN}

Pendidikan yang berhasil adalah pendidikan yang dapat membentuk perilaku manusia, bukan sekedar membekali manusia dengan pengetahuan dan informasi saja. Oleh karena itu pedoman moral, nilai, dapat ditanamkan melalui pendidikan karakter Kristen. Nilai-nilai moral yang ditanamkan akan membentuk karakter yang merupakan fondasi penting untuk menghasilkan pribadi yang utuh bagi dirinya dalam menyikapi kehidupan. Pendidikan karakter Kristen menanamkan prinsip-prinsip moral berdasarkan pada Alkitab artinya Alkitab menentukan apakah sesuatu benar atau salah. Dalam kekristenan Firman Tuhan adalah nilai moral yang absolut. Nilai-nilai dalam Alkitab memiliki definisi yang tidak berubah. Jadi pengetahuan saja tidak cukup. Oleh karena itu strategi pembelajaran akan memampukan orang untuk bertumbuh dalam penerapan karakter yang diinginkan sesuai dengan kehendak-Nya. Namun apakah pendidikan karakter yang paling esensi untuk mengubah karakter manusia kepada karakter mulia? Untuk memahami hal ini, maka di bawah ini akan diuraikan berturut-turut mengenai Tujuan Penelitian: (1). Apakah pengertian pendidikan karakter Kristen? (2). Bagaimanakah peran pendidikan karakter kristen terhadap pengembangan sikap batin peserta didik? (3). Bagaimanakah Implikasi Natur Ketidakmampuan Total Manusia?

\section{METODE}

Penelitian ini menggunakan metode kualitatif dengan pendekatan deskriptif dan studi pustaka, bertujuan untuk menyajikan informasi $^{1}$ dengan metode untuk menggambarkan suatu hasil penelitian. Namun, hasil gambaran tersebut tidak

${ }^{1}$ H.B. Sutopo, Metodologi Penelitian Kuantitatif (Surakarta: Universitas Sebelas Maret Press, 2006), 25.

72 | Vol. 4 No. 2 (Desember 2020) digunakan untuk membuat kesimpulan yang lebih umum.

\section{PEMBAHASAN}

\section{Pengertian Pendidikan Karakter Kristen}

Sebagaimana dijelaskan di atas bahwa pendidikan yang berhasil adalah pendidikan yang dapat membentuk perilaku manusia, bukan sekedar membekali manusia dengan pengetahuan dan informasi saja. Oleh karena itu pedoman moral, nilai, dapat ditanamkan melalui pendidikan karakter Kristen. Lalu apakah yang dimaksud dengan pendidikan Kristen? Untuk memahami hal ini, maka akan dipaparkan terlebih dahulu pengertian dari karakter Kristen, sehingga beroleh pemahaman yang jelas mengenai pengertian pendidikan karakter Kristen.

\section{Karakter Kristen}

Tema tentang karakter adalah bahasan yang penting, tetapi jarang dibicarakan dan telah diabaikan, bahkan dikalangan Kristen sekalipun. Dua kemungkinan alasan pengabaian ajaran ini adalah : (1) Bahasan ini dianggap kurang menarik dibanding dengan tema doktrinal lainnya; (2) Tidak semua orang suka membahas karakter karena ini menyangkut wilayah "kepribadian" seseorang yang dianggap tidak boleh diusik. Akibat dari pengabaian ini banyak orang Kristen yang tidak mengetahui ajaran dari tema yang sangat penting ini, ${ }^{2}$ Padahal dalam pengajaranNya Yesus sangat menekankan karakter para muridNya. Para murid utama Tuhan Yesus yang dua belas itu setiap hari bersama-sama dengan Tuhan Yesus, Guru mereka kemana pun Tuhan pergi. Dengan sengaja Tuhan menyediakan waktu hanya

${ }^{2}$ Samuel T, Gunawan, Membangun dan Mengembangkan Karakter Kristen yang Kuat, dalam Khotbah Ibadah Raya GBAP EL Shaddai, (Palangka Raya: tidak diterbitkan, 2013), 1. 
untuk bersama-sama dengan murid-muridNya. Misalnya dalam Injil Matius (10:1-4; 13:10 dst, 16:5 dst; Mat 17:1 dst; 18:1 dst; 24:1 dst; 26:17 dst). Mereka bukan hanya hadir melainkan menyaksikan saat Tuhan Yesus berkhotbah, mengajar, atau saat Tuhan Yesus berdiskusi bahkan berdebat dengan para pemimpin Yahudi. Mereka juga menyaksikan saat Tuhan membuat muzijat, atau melakukan konseling pribadi. Hidup dan sikap Tuhan Yesus mereka saksikan dan teladani, karena hal itu adalah model pendidikan yang Tuhan langsungkan selama Tuhan berkarya di Kanaan. Tekanan utama dari model pendidikan ini adalah kualitas hidup/karakter atau mutu spiritualnya. Hal di atas adalah pola pembinaan yang dilakukan Tuhan Yesus untuk menyiapkan para murid-Nya sebelum akhirnya mereka di utus (Mat 28:19-20). Kesaksian Inji-Injil tentang pola pembinaan Tuhan Yesus terhadap murid-murid-Nya jelas bahwa mutu karakter mendapat perhatian besar. Para murid Tuhan itu lebih banyak belajar tentang kehidupan daripada belajar tentang doktrin. Bahkan sering Tuhan mengecam pola hidup kaum Farisi yang mengenal banyak hukum keagamaan (tentu hal itu telah menjadi doktrin mereka) namun hidup mereka tidak seirama dengan doktrin yang mereka ajarkan (Mat 23:1-3). Hal itu menunjukkan bahwa bagi Tuhan, karakter/kesaksian kehidupan itu teramat penting. ${ }^{3}$ Terlebih hal itu penting diajarkan kepada mereka/murid-murid Yesus yang akan memimpin gereja mula-mula. ${ }^{4}$

${ }^{3}$ Purnawan Tenibemas, Spiritualitas di Sekolah Teologi, dalam Jurnal Teologi Pengarah STA Tiranus, (Bandung: STA Tiranus, 2010), 2-10.

${ }^{4}$ Wofford, J.C, Kepemimpinan Kristen Yang Mengubahkan, terj, (Yokyakarta: ANDI, 2001), 115116.
Hal mengenai pembinaan karakter ini terus berlangsung atau dilanjutkan oleh para rasul. Surat Paulus kepada Timotius dan Titus juga berbicara mengenai karakter pemimpin gereja (2 Tim 2:2). Karakter itu meliputi kualitas seperti: Integritas, kemurnian moral, kelemahlembutan dan kesabaran. Tekanan pentingnya memiliki kualitas kehidupan/karakter ini tentu bukan hanya berlaku untuk para murid khusus atau para pemimpin, namun cocok untuk semua orang percaya ${ }^{5}$. Kualitas karakter dibahas diseluruh Perjanjian Baru. Tragisnya, akibat ketidaktahuan akan hal ini, banyak orang Kristen tidak bertumbuh dalam karakter Kristen yang baik, dan lebih buruk lagi, tetap merasa bertumbuh padahal stagnan. ${ }^{6}$ Jadi apakah yang dimaksud dengan karakter Kristen?

Karakter adalah, tabiat; watak; sifatsifat kejiwaan atau budi pekerti yang membedakan seseorang dari yang lainnya. Karakter adalah istilah psikologis yang menunjuk kepada "sifat khas yang dimiliki oleh individu yang membedakannya dari individu lainnya". Jadi, pada dasarnya karakter adalah sifat-sifat yang melekat pada kepribadian seseorang. Dengan kata lain, karakter adalah sikap batin yang mempengaruhi atau tampak dalam pikiran, perasaan dan perbuatan atau perilaku. Sering kali juga disebut sebagai watak, perangai, akhlak, kelakuan, ${ }^{8}$ yang sudah tertanam dan berurat berakar serta telah menjadi ciri khas

${ }^{5}$ Purnawan Tenibemas, Spiritualitas di Sekolah Teologi, dalam Jurnal Teologi Pengarah STA Tiranus, (Bandung: STA Tiranus, 2010), 2-10.

${ }^{6}$ Samuel T, Gunawan, Membangun dan Mengembangkan Karakter Kristen yang Kuat, dalam Khotbah Ibadah Raya GBAP EL Shddai, (Palangka Raya: tidak diterbitkan, 2013), 2.

${ }^{7}$ W.J.S Poerwadarminta, Kamus Umum Bahasa Indonesia, (Jakarta: Balai Pustaka).

${ }^{8}$ BS. Sidjabat, Membesarkan Anak Denga Kreatif, (Jogyakarta: ANDI, 2008), Cet 1, 3. 
diri kita sendiri (Personalitas). Karena itu, apakah dilihat orang lain atau tidak, kita akan memperlihatkan perangai itu (Konsisten). ${ }^{9}$ Sedangkan Kristen adalah sebutan bagi seseorang yang telah menerima Yesus Kristus sebagai Tuhan dan Juruselamat secara pribadi serta meneladani hidup dan ajaran-ajaranNya dalam kehidupan sehari-hari. Dengan demikian, karakter Kristen disebut juga sifat-sifat Kristen, yaitu kualitas rohani yang dimiliki seorang Kristen. Jadi dengan pemahaman di atas, diperoleh pengertian bahwa pendidikan karakter Kristen adalah pendidikan yang membentuk dan mengembangkan sikap batin peserta didik supaya mampu bersikap dan berperilaku bijak, serta bertanggung jawab dalam kehidupannya sehari-hari sebagai orang Kristen. ${ }^{10}$

\section{Landasan Teologi Pendidikan Karakter Kristen}

Dilihat dari pandangan Alkitab, sebenarnya bertumbuh dalam watak/karakter /budi pekerti merupakan kehendak Tuhan. Menurut Firman Tuhan, setelah orang-orang Sungguh-sungguh percaya atau beriman kepada Yesus Kristus, hidup mereka haruslah sesuai dengan keyakinan itu. Firman Tuhan dalam Efesus 4:1-2 mengatakan," ...supaya hidupmu berpadanan dengan panggilan itu. Hendaklah kamu selalu rendah hati, lemah lembut, dan sabar. Tunjukkanlah kasihmu dalam hal saling membantu...”juga dikemukakan:"...jangan hidup lagi sama seperti orang-orang yang tidak mengenal Allah dengan pikirannya yang sia-sia dan pengertiannya yang gelap, jauh dari persekutuan dengan Allah...'(Efesus 4:17-18). Dalam bagian lain dikemukakan:"Sebab itu jadilah penurutpenurut Allah, seperti anak-anak yang kekasih dan hiduplah dalam kasih, sebagaimana Kristus Yesus juga telah mengasihi kamu dan telah menyerahkan

${ }^{9}$ BS. Sidjabat, Membangun Pribadi Ungggul, (Jogyakarta: ANDI, 2011), Cet.1, 2.

${ }^{10}$ BS. Sidjabat, Membesarkan Anak Denga Kreatif, (Jogyakarta: ANDI, 2008), Cet 1, 3. 74 | Vol. 4 No. 2 (Desember 2020)
diri-Nya untuk kita sebagai persembahan korban yang harum bagi Allah" (Ef 5:1-2).

Rasul Paulus menasehati agar orang Kristen senantiasa berkomitmen membuang dan mematikan segala karakter buruk dari kehidupan mereka, seperti marah, geram, kejahatan, fitnah dan kata-kata kotor (Kol 3:5-11). Pada saat bersamaan mereka harus belajar atau melatih diri mengenakan belas kasih, kemurahan, kerendahhatian, kelemahlembutan dan kesabaran (3:12-17). Sifat-sifat ini tak lain ialah perangai hidup Yesus Kristus yang telah menebus orang percaya itu sendiri. Hidup orang percaya telah tersembunyi dalam Kristus dan secara spiritual menyatu dengan Dia. Semua ini merupakan pekerjaan Allah (3:3; Bdk. Rm 6:6-11; Gal 2:20). Jadi, bertumbuh dengan karakter yang mulia menjadi sangat mungkin terjadi dalam kehidupan orang Kristen.

Karakter yang kita dambakan bertumbuh dalam hidup ini dalam persfektif iman Kristen, sesungguhnya adalah watak Kristus Yesus yang bersemai dan berkembang dalam diri orang percaya, sebagai pekerjaan Roh Kudus. Alkitab mengajarkan bahwa kalau hendak bertumbuh dalam karakter yang baik, Yesus mengajak orang datang kepada-Nya dan belajar kepada Dia, sebab menurut-Nya, Dia lemah lembut dan rendah hati yang sanggup memberi kelegaan hati bagi yang berbeban berat dan ketenangan jiwa bagi yang gelisah (Mat 11:28-30). Juga dikemukakan oleh Yesus bahwa dengan tinggal dalam Dia (melalui tindakan iman), tinggal dalam firman-Nya serta dalam kasih-Nya, orang dapat berbuah dengan perangai mulia (bdk. Yoh 15:4,5,7,9). Dia sendirilah yang telah memilih dan menetapkan orang percaya untuk berbuah dalam kehidupan mereka (15:16).

Jadi pendidikan karakter yang tepat sebenarnya harus dimulai dengan perjumpaan pribadi seseorang dengan Yesus. Alkitab menyatakan bahwa ketika orang membuka dirinya bagi Yesus, mengaku percaya dengan Sungguh (bdk.rm 
10:9-10), Roh Yesus hadir dalam dirinya. Roh itulah yang kemudian mengerjakan tabiat baru. Akhlak mulia, yang berasal dari Kristus. Di dalam atau oleh karena Yesus sendirilah kehidupan kita dapat berubah sehingga yang lama berlalu dan yang baru datang (bdk. 2 Kor 5:17). Pendidikan dan pembelajaran karakter merupakan alat bantu, media atau sarana dalam pembentukan pribadi manusia. Dalam proses itu berbagai akhlak luhur diperbincangkan, termasuk kejujuran, kebajikan, keberanian, kedisiplinan, kemurahan, toleransi, tanggung jawab. Akan tetapi sumbernya dari mana? Dari filsafat dan tradisi manusiawi atau dari Firman Tuhan? Kuasa yang menanamkan nilai dan akhlak itu siapa? Oleh karena kesadaran dan latihan atau diperlukan campur tangan dari luar diri kita?

Menurut Alkitab Roh Allah yang dimateraikan pada diri orang percaya (bdk. Rm 5:3; 8:9-15; Ef.1:13-14) sanggup mengubah akhlak kita. Itulah tugasnya datang ke dunia sejak pentakosta, hari kelima puluh hari setelah Yesus bangkit dari kubur. Dia diutus sebagai penolong atau pendamping (paracletos) orang percaya. Roh itu mengubah orang percaya dari waktu ke waktu, sehingga mereka hidup sesuai dengan watak Kristus (bdk. 2Kor 3:17-18). Karena itu, Paulus mendesak jemaat Galatia untuk memberi diri dipimpin, hidup oleh dan berjalan bersama Roh Kudus supaya buah Roh Kudus-kasih, sukacita, damai sejahtera, kesabaran, kemurahan, kebaikan, kesetiaan, kelemahlembutan dan penguasaan diri-muncul dan berkembang dalam batin, pikiran dan perasaan mereka (Gal 5:16-18, 22-23, 25).

Dalam kitab Efesus rasul Paulus juga mendesak supaya orang percaya memberi diri dipenuhi Roh Kudus (kehadiran-Nya) agar mereka bertumbuh pikiran, perasaan positif, dan mampu bersyukur dalam keadaan buruk sekalipun, serta cakap untuk rendah hati kepada yang lain (ef. 5:18-21).
Sebenarnya hal ini sudah pernah ditegaskan Nabi Yehezkiel pada masa lalu ketika ia menyatakan janji Allah bagi bangsa Israel yang terbuang ke Babel selama 70 tahun. Bagi Yehezkiel, Dialah (Roh itu) yang sanggup memberi hati yang baru, roh yang baru, hati yang taat kepada Tuhan dan perintah-perintah-Nya umat yang cenderung berbuat jahat dan memberontak (Yeh.36:2527). ${ }^{11}$

Dengan melihat landasan Teologis Pendidikan Karakter, jelas bahwa yang terpenting $\mathrm{di}$ atas semuanya adalah seseorang harus mengalami perjumpaan dengan Yesus (lahir baru). Mengaku percaya dengan sungguh, sehingga Roh Yesus hadir dalam dirinya, mengerjakan tabiat baru yang berasal dari Kristus. Maka agent-agent pendidikan yang Yesus percayakan, sudah mulai leluasa untuk mendidik orang percaya karena Roh Yesus sudah ada di hatinya.

\section{Peran Pendidikan Karakter Kristen terhadap Pengembangan Sikap Batin Peserta Didik}

Ada sejumlah alasan mengapa pendidikan karakter Kristen itu penting untuk diajarkan dan ditampilkan, oleh karena tantangan di abad 21 ini semakin bersifat variatif, akumululatif, sistematis, dan masif, respon orang Kristen justru semakin reaktif, tantangan itu diantaranya: (1) Kemerosotan moral. Salah satu tantangan yang terus muncul dipermukaan berkaitan dengan LGBT. Reaksi secara umum kerap kali diperlihatkan dengan menunjukkan penentangan, secara verbal atau pun nonverbal, baik melalui media sosial di dunia maya maupun melalui media lainnya. Ada juga yang menempuh jalur legal dan formal. Alih-alih mengatasi permasalahan, tak jarang justru secara tidak langsung yang terjadi adalah isu itu sendiri semakin "terpromosikan". Konsekuensi

${ }^{11}$ BS. Sidjabat, Membesarkan Anak dengan Kreatif, (Jogyakarta: ANDI, 2008), Cet.1, hal 5-7. 
logisnya, permasalahan itu merambah ke kalangan jemaat, aktivis, sampai ke keluarganya, bahkan para rohaniawan. Hal itu menimbulkan pertanyaan: Mengapa masalah ini tak selesaikan hingga kini, padahal hal ini bukanlah perkara baru sudah sejak peristiwa Sodom adan Gomora, sekitar 2000 tahun SM? Sebaliknya, masalah itu justru semakin menggurita dengan jumlah pelaku yang semakin banyak, penyimpangan perilaku seksual yang semakin kompleks, sistem penyebaran atau penularan yang semakin gencar, dan jangkauan rentang usia yang semakin lebar.

Perilaku seksual yang semakin komplek sebagaimana yang terjadi akhirakhir ini, yaitu dikejutkan dengan adanya sexual abuse ${ }^{13}$, yang melibatkan banyak individu dari berbagai strata, umur, pendidikan, dan status sosial. Contoh kasus; Emon dari Sukabumi melakukan aksi pedofilia $^{14}$ terhadap 110-118 anak dengan

${ }^{12}$ Tan Giok Lie, Pendidikan Kristen Menjawab Tantangan Abad Ke-21, dalam Menjadi Hamba Yang Setia, Cendikia, Dan Berhati Mulia, (Bandung, STA Tiranus:2016), Cet.1, 111

${ }^{13}$ Sexual abuse adalah bentuk kekerasan seksual, baik berupa pelecehan maupun perkosaan. Pemahaman lebih lengkap mengenai sexual abuse dapat dilihat dari beberapa sudut pandang. Misalnya, dari sudut pandang kriminal, perlakukan dari pelaku (offender) terhadap anak-anak merupakan kejahatan atau sexual crime. Dari sudut psychological, Sexual abuse merupakan bagian dari psikologi abnormal (Psychopatology). Artinya sexual abuse merupakan perilaku seksual yang telah melanggar norma-norma atau ketetapan atau aturan yang normal. Lihat Rudy A. Alouw, Konseling Intervensi Bagi Anak Korban Sexual Abuse, dalam Menjadi Hamba Yang Setia, Cendikia, Dan Berhati Mulia; Sebuah Antologi, (Bandung: STA Tiranus, 2016), Cet.1, hal 145.

${ }^{14}$ Pedofilia, yang berasal dari kata Yunani pais yang berarti 'anak' dan philia yang berarti 'cinta atau kasih pertemanan atau persaudaraan'. Anak yang dimaksudkan disini berusia praremaja. Jadi, yang dimaksudkan pedofilia adalah perilaku seksual orang dewasa terhadap anak-anak yang berusia antara 1-11 tahun. Lihat Rudy A. Alouw, Konseling Intervensi Bagi Anak Korban Sexual Abuse, dalam Menjadi Hamba Yang Setia, Cendikia, Dan Berhati Mulia; Sebuah Antologi, (Bandung: STA Tiranus, 2016), Cet.1, hal 144.

76 | Vol. 4 No. 2 (Desember 2020) iming-iming uang 20-50 ribu rupiah. Ada juga seorang anak usia 9 tahun yang mencabuli teman sebayanya ${ }^{15}$. Masih banyak contoh lainnya dalam hal penyimpangan seks ini. Kemorosotan moral juga terjadi melalui kemajuan teknologi di era ini, percakapan penting dan/atau obrolan santai antar individu dalam lintas negara, dapat dilakukan kapan saja melalui Televisi, layar Monitor komputer, telepon genggam ${ }^{16}$ juga melalui Washap dan Facebook, tetapi dibalik aneka kemudahan, juga menghadirkan sederet kecemasan, kekuatiran di relung hati dalam banyak hal para wanita cantik, tak segan memamerkan kemolekan tubuhnya di panggung pertunjukan dengan mengenakan busana tembus pandang, berukuran mini, super ketat, bermodalkan hak asasi. ${ }^{17}$ Dampak negatif dari Facebook dan Washap maraknya perselingkuhan dan perceraian. Bahkan anak SMP, SMA mau melakukan praktek prostitusi.

Masalah penurunan moral lainnya berhubungan juga dengan beratnya tantangan hidup, khususnya secara ekonomi dan moneter, telah membuat orientasi tujuan hidup orang berubah. Ada orang yang karena ingin cepat kaya dan merasa bermakna, larut dalam korupsi sekalipun suara hatinya berkata salah. Sebagian kelompok masyarakat, walau telah bekerja keras, tetap saja merasakan bahwa nasibnya tidak meningkat, terpuruk secara ekonomi, sebagaimana yang dialami para buruh pabrik dan petani. Jurang antara si kaya dan simiskin melebar serta menimbulkan rasa

${ }^{15}$ Rudy A. Alouw, Konseling Intervensi Bagi Anak Korban Sexual Abuse, dalam Menjadi Hamba Yang Setia, Cendikia, Dan Berhati Mulia; Sebuah Antologi, (Bandung: STA Tiranus, 2016), Cet.1, hal 141.

${ }^{16}$ Nimrod F. Faot, Spiritualitas Dan Postmodernitas Duet Atau Duel?, dalam Jurnal Teologi Pengarah, (Bandung: STA Tiranus, 2010), hal 29.

${ }^{17}$ Nimrod F. Faot, Spiritualitas Dan Postmodernitas Duet Atau Duel?, dalam Jurnal Teologi Pengarah, (Bandung: STA Tiranus, 2010), hal 29. 
ketidakadilan. Tindakan kekerasan demi mempertahankan kehidupan seperti merampok, menjambret, dan menipu, merupakan salah satu akibat dari krisis multidimensi di negeri ini. ${ }^{18}$ Penurunan moral lainnya, yang pada umumnya banyak menimpa remaja, di antaranya penggunaan minuman beralkohol, narkoba dan masih banyak yang lainnya.

Itu barulah beberapa permasalahan kontemporer yang dihadapkan kepada orang Kristen pada umumnya dan para pemimpin Kristen khususnya. Masihkah berpikir bahwa itu dapat diselesaikan secara reaktif dan pragmatis. ${ }^{19}$ Tampaknya, suatu tantangan global lebih membutuhkan suatu solusi yang komprehensif dan fundamental, yang menyentuh akar permasalahan. Untuk itu dibutuhkan pengajaran karakter yang merupakan perlawanan terhadap kemerosotan moral dan terhadap etika modern yang rasionalistik yang dipengaruhi oleh pencerahan dan individualistik;

(2) Bahaya Relativisme/pluralisme. Melahirkan pula gaya hidup konsumeris hedonis. Bermunculan biro perjalanan online, karena derasnya arus pelancong guna memuaskan keinginan mata dan rasa. Iklan wisata tak terbendung dalam dunia maya dan dunia nyata. Kuliner, factory outlet, super mall serba ada tumbuh subur. Alfamart dipinggiran kota, memangsa habis warung tradisional. Sebab berbelanja bukan lagi sekedar pemenuhan kebutuhan pribadi/keluarga, tapi menjadi lifestyle atau kesenangan. Karena selera berbelanja ini, bank-bank berlomba menerbitkan kartu kredit yang begitu mudah didapatkannya, guna memperlancar transaksi melalui toko-

\footnotetext{
${ }^{18}$ BS. Sidjabat, Jangan Lupakan Teladan Yesus, Sang Guru Agung, dalam Jurnal Teologi Pengarah, (Bandung: STA Tiranus, 2010), hal 91.

${ }^{19}$ Tan Giok Lie, Pendidikan Kristen Menjawab Tantangan Abad ke -21; Suatu Pendekatan Reformatif, dalam Menjadi Hamba Yang Setia, Cendikia, Dan Berhati Mulia; Sebuah Antologi, (Bandung: STA TIRANUS, 2016), Cet.1, 111-112.
}

toko online. Setidaknya ada lima masalah penting yang ditimbulkan oleh gaya hidup konsumeris hedonis: Konsumersime berpusat pada diri sendiri, menyanjung pilihan, menjadi ketergantungan, membentuk nilai-nilai sosial individu, menjanjikan kebebasan. Warga gereja terkepung oleh konsumeris hedonis, dan sebagian terpengaruh olehnya, sebagai contoh, sebagian pendeta berlomba mengiklankan diri sebagai tour guide ke berbagai negara tujuan wisata, terutama ke holyland. Beribadah, berbelanja, makan dan melancong, menjadi satu paket dalam kehidupan masyarakat umumnya. Manusia berpusat pada dirinya, bukan Tuhan Allah. Situasi ini sudah seharusnya disikapi sebagai ilah zaman, yang dijadikan tempat pelarian karena terjadi kekeringan rohani. Seharusnya, gereja sedih dengan fenomena ini, seperti rasul Paulus ketika menyaksikan barang-barang pujaan masyarakat di kota Atena (Kis 17:16, 22-23). ${ }^{20}$

\section{Oleh karena pengaruh}

Pluralisme/Relativisme dan juga adanya aspek kemiskinan, daerah kantong kristen pun mengalami pengikisan. Banyak orang kristen beralih keyakinan sekedar untuk mendapatkan bantuan finansial atau beasiswa. Dulu orang Kristen dituduh menyelewengkan bantuan sosial untuk mengkristenkan, kini justru banyak orang Kristen di wilayah ini menjadi korban bujukan bantuan sosial. Tekanan sosial politik dari keyakinan lain pun turut berperan "membocorkan" kantong Kristen ini. Dengan alasan demi karier, jabatan, pangkat atau status, banyak orang Kristen di wilayah ini rela berganti keyakinan. Demikian juga orang-orang Kristen yang keluar dari wilayah kantong Kristen, untuk mencari pekerjaan atau study ke wilayah

\footnotetext{
${ }^{20}$ Nimrod F. Faot, Merintis Gereja Misioner Di Tengah Ancaman Penganiayaan, dalam Setia Sebagai Pewarta Kabar Baik; Festschrift 70 Tahun Dr. Purnawan Tenibemas, (Bandung, STA Tiranus, 2017), Cet.1, 96.
} 
yang mayoritas berkeyakinan lain, demi keamanan dan kemudahan mendapatkan pekerjaan banyak dari orang Kristen perantau ini ynag rela meninggalkan iman Kristennya. ${ }^{21}$ Keadaan ini tentu saja, sangat membutuhkan pendidikan karakter Kristen, agar kehidupan kekristenan di tempat ini menjadi berakar, sehingga tidak mudah tergoyahkan oleh situasi dan kondisi yang disekitarnya.

(3) Pudarnya semangat keteladanan. Karakter dibentuk oleh orang-orang lain yang menjadi model atau mentor; Orang tua, guru, pembina, pelatih yang menjadi model atau teladan, turut membentuk karakter nara didik. Dengan dituntun atau mengikuti dan meneladani para pembina atau sosok lain yang layak diteladani, nara didik belajar mengenali dan mewujudkan berbagai disposisi, kebiasaan, dan keterampilan emosional dan intelektual yang dinyatakan oleh berbagai kebajikan. Sayangnya, kebanyakan teori etika individualistik dan rasionalistik modern kurang memperhatikan pengaruh-pengaruh ini, atau dengan kata lain semangat untuk mewarisi keteladanan kebenaran ini semakin memudar. ${ }^{22}$ Banyak para pendidik dan guru Kristen yang pudar semangat idealismenya. Ada pendidik yang benar-benar ingin mempersembahkan profesinya bagi kemuliaan Tuhan. Namun, karena tuntutan, tekanan, dan tantangan kehidupan yang begitu besar, akhirnya mereka hanya bekerja demi mempertahankan kehidupan (survival for living). Tugas mengajar, baik di sekolah maupun gereja, bisa jadi hanya bersifat rutin. Ada juga yang menjadikan anak didik sebagai objek dan sumber penghasilan (misal dengan memberikan les privat dari rumah ke rumah). Tidak sedikit guru yang menjadi agen penjual buku kepada anak didik agar memiliki tambahan penghasilan. Bahkan ada yang tega membocorkan soal

\footnotetext{
${ }^{21}$ Purnawan Tenibemas, Andil Kita Dalam Misi Masa Kini, dalam Pengarah Jurnal Teologi Kristen, (Bandung: STA Tiranus, 2019), hal 31-32.

${ }^{22}$ Stephen Tong, Arsitek Jiwa II, (Jakarta: Momentum, 2010), Cet.7, 25-26.
}

78 | Vol. 4 No. 2 (Desember 2020) ujian kepada anak didik dari keluarga berada atau menjadi semacam joki ujian untuk mereka. $^{23}$

Inilah serentetan, problema yang terjadi di abad 21 ini, yang mendesak pentingnya peran pendidikan karakter Kristen. Karena Alkitab mengajarkan bahwa iman Kristen sifatnya holistik. Artinya, iman sebagai pengetahuan, iman sebagai pengakuan (konfesi) dan keyakinan, serta iman sebagai perbuatan nyata haruslah terintegras dalam kehidupan. Bukankah Allah menciptakan manusia itu sebagai makhluk yang mempunyai roh, jiwa dan tubuh (bdk 1 Tes 5:23)? Bukankah Tuhan menciptakan manusia sebagai makhluk pribadi dan mahluk sosial-kultural (bdk Kej 1:26-28; 2:7)? Jadi, kalau anak di bimbing untuk beriman kepada Allah di dalam Yesus Kristus, imannya harus tampak dalam perbuatan. Tidak sekedar pada tataran pengetahuan dan pengertian. Dalam Perjanjian Baru, rasul Yakobus menegaskan bahwa iman tanpa perbuatan pada hakikatnya iman yang mati (Bdk Yak 2:17, 26). ${ }^{24}$ Identitas orang Kristen dikenal lewat dua kualitas transformatif yang secara metaforis dinyatakan sebagai "garam" dan "terang" dunia (Matius 5:13,14). Kedua metafora ini mengacu kepada "perbedaan" dan "pengaruh" yang harus dimanifestasikan murid-murid Yesus kepada dunia ini. Kedua metafora ini dapat diartikan sebagai "penetrating power of the Gospel" yang harus dinyatakan oleh murid-murid Yesus yang sudah lebih dahulu mengalami transformasi. Implikasi dari penegasan ini cukup serius, yaitu bahwa orang Kristen harus memikul beban moral dari metaforametafora ini secara konsisten dan konsekuen. Lebih jauh, implikasi ini bukan sekedar penegasan, tetapi merupakan sebuah panggilan bagi orang Kristen untuk

\footnotetext{
${ }^{23}$ BS. Sidjabat, Jangan Lupa Teladan Yesus, Sang Guru Agung, dalam Menjadi Hamba Yang Setia, Cendikia, Dan Berhati Mulia, (Bandung: STA Tiranus, 2016), Cet. 1, 92

${ }^{24}$ Sijabat BS, Membesarkan Anak Dengan Kreatif, (Jogyakarta: ANDI, 2008), Cet. 1, 1-2.
} 
melibatkan diri dan memberi solusi dalam masalah-masalah dunia ini tanpa harus menjadi duniawi. ${ }^{25}$

Sebagaimana telah diketahui, bahwa teori pendidikan karakter pada umumnya berpendapat bahwa karakter atau perangai manusia dapat ditumbuhkembangkan dengan latihan-latihan. Diyakini bahwa pada dasarnya manusia itu baik dan mempunyai potensi kebaikan. Potensi kebaikan itulah yang harus mendapat perhatian. Kemudian disuburkan atau dibangkitkan supaya orang berperangai dengan kebiasaan itu. Pengajaran mengenai nilai hidup dan moral harus diaktifkan. Selain itu lingkungan keluarga, sekolah atau masyarakat juga harus dibina agar menjadi konteks sosial yang konduktif bagi pertumbuhan karakter mulia. Namun pandangan ini tidak sepenuhnya benar. Sebab, kenyataannya manusia cenderung melakukan yang buruk dalam hidupnya seperti yang dinyatakan Rasul Paulus, beliau mengemukakan bahwa ia tahu secara kognitif tentang apa yang baik dan harus dilakukan tetapi dalam anggota tubuhnya terdapat desakan untuk berpikir, merasa dan bertindak sebaliknya. Ia merasa kelelahan. Bahkan kecewa terhadap dirinya (Rm 7:15). ${ }^{26}$ Pertanyaannya, mengapa kecenderungan manusia melakukan hal yang buruk? Karena manusia telah mati secara rohani akibat pelanggarannya terhadap hukum Allah, sehingga manusia mengalami kerusakan total dan ketidakmampuan total, keadaan ini membuat manusia tidak dapat melakukan hal yang benar menurut pandangan Tuhan. Untuk lebih jelasnya, penulis memaparkan lebih lanjut sebagaimana diuraikan di bawah ini.

\section{Implikasi Natur Ketidakmampuan Total Manusia}

\footnotetext{
${ }^{25}$ Samuel T. Gunawan, Membangun Dan Mengembangkan Karakter Kristen yang Kuat, (Palangkaraya:belum diterbitkan, 2013), 3.

${ }^{26}$ Sijabat BS, Membesarkan Anak Dengan Kreatif, (Jogyakarta: ANDI, 2008), Cet. 1, 8.
}

Manusia telah mati secara rohani sehingga memerlukan kelahiran kembali atau hidup baru secara rohani. Akibat dari dosa pertama Adam dan Hawa, citra Allah dalam diri manusia telah tercoreng dan mengakibatkan dosa masuk dan menjalar kepada setiap manusia (Roma 3:10-12, 23; 5:12). Adam dan Hawa telah membuat dosa menjadi aktual pada saat pertama kalinya di Taman Eden, sejak saat itu natur dosa telah diwariskan kepada semua manusia. (Roma5:12;1Korintus15:22). Manusia telah rusak total (total depravity), tetapi ini bukanlah berarti: (1) bahwa setiap orang telah menunjukkan kerusakannya secara keseluruhan dalam perbuatan, (2) bahwa orang berdosa tidak lagi memiliki hati nurani dan dorongan alamiah untuk berhubungan dengan Allah, (3) bahwa orang berdosa akan selalu menuruti setiap bentuk dosa, dan (4) bahwa orang berdosa tidak lagi mampu melakukan hal-hal yang baik dalam pandangan Allah maupun manusia. Tetapi yang dimaksud dengan kerusakan total adalah: (1) kerusakan akibat dosa asal menjangkau setiap aspek natur dan kemampuan manusia: termasuk pikiran, hati nurani, kehendak, hati, emosinya dan keberadaannya secara menyeluruh (2 Korintus 4:4,1 Timotius 4:2; Roma 1:28; Efesus 4:18; Titus 1:15), dan (2) secara natur, tidak ada sesuatu dalam diri manusia yang membuatnya layak untuk berhadapan dengan Allah yang benar (Roma3:10-12).

Selain mengakibatkan kerusakan total pada manusia, dosa juga mengakibatkan ketidakmampuan total (total inability), yaitu bahwa : (1) Orang yang belum lahir baru tidak mampu melakukan, mengatakan, atau memikirkan hal yang sungguh-sungguh diperkenan Allah, yang sungguh-sungguh menggenapi hukum Allah; (2) Tanpa karya khusus dari Roh Kudus, orang yang belum lahir baru tidak mampu mengubah arah hidupnya yang mendasar, dari dosa mengasihi diri sendiri menjadi kasih kepada Allah. Perlu ditegaskan bahwa ketidakmampuan total bukanlah berarti orang yang belum lahir baru sesuai naturnya tidak mampu melakukan apa yang baik dalam pengertian apapun. Ini berarti, orang yang belum lahir baru masih mampu melakukan bentukbentuk kebaikan dan kebajikan tertentu. Tetapi perbuatan baik ini tidak digerakan oleh kasih kepada Allah dan tidak pula dilakukan dengan ketaatan yang sukarela pada kehendak Allah. 
Jadi, manusia dalam natur lamanya yang berdosa tidak menyadari dan tidak mampu menanggapi hal-hal rohani dari Allah. Manusia tidak mampu melakukan apapun untuk mengubah natur maupun keadaan keberdosaannya (Roma 3:9-20). Maka jelaslah bahwa manusia memerlukan suatu perubahan yang radikal dan menyeluruh yang memampukannya untuk dapat kembali melakukan hal yang benar menurut pandangan Tuhan. Lahir Baru/hidup baru adalah solusi yang disediakan Allah bagi manusia. ${ }^{27} \mathrm{Hal}$ ini sebagaimana yang dikatakan Paulus, ia meyakini bahwa yang dapat membebaskan dirinya dari belenggu sikap mental negatif itu hanyalah Yesus Kristus, sumber kemenangan terhadap dosa dan kuasa dosa ( $\mathrm{Rm}$ 7:15-26). Jadi jelas mendambakan perubahan karakter yang radikal dan menyeluruh harus bertolak dari dasar teologis, sehingga pembentukan dan pengembangan akhlak mulia akan positif. ${ }^{28}$ Dengan demikian, pendidikan karakter yang tepat sebenarnya harus dimulai dengan perjumpaan pribadi seseorang dengan Yesus (lahir baru), pendidikan dan pembelajaran karakter merupakan alat bantu, media atau sarana dalam pembentukan pribadi manusia. Dasar teologis inilah yang menjadi landasan pendidikan karakter Kristen. Untuk mengetahui lebih jelas bagaimana proses lahir baru (perjumpaan dengan Yesus) dan pengaruh perjumpaan tersebut terhadap karakter nara didik/warga gereja, perlu menyimak isi dari landasan teologi pendidikan karakter Kristen, sebagaimana penulis uraikan di bawah ini.

\section{Agent-agent pendidikan Karakter Kristen}

Sebagaimana dikatakan di atas bahwa mendambakan perubahan karakter yang radikal dan menyeluruh seseorang harus mengalami perjumpaan dengan Yesus, maka karakter yang mulia akan terpancar

${ }^{27}$ Anthony A. Hoekema, Diselamatkan Oleh Anugerah, Terjemahan, (Jakarta: Momentum, 2010), 121-146.

${ }^{28}$ Sijabat BS, Membesarkan Anak dengan Kreatif, (Jogyakarta: ANDI, 2008), Cet. 1, 8.

80 | Vol. 4 No. 2 (Desember 2020) dari praktek hidupnya. Dengan demikian, pendidikan dan pembelajaran karakter merupakan alat bantu, media atau sarana dalam pembentukan pribadi manusia. Agent dalam pendidikan karakter di antaranya keluarga, guru di sekolah, dan gereja. Dan para ahli psikologi dan pendidikan menyatakan bahwa lingkungan dan agen paling banyak mempengaruhi pembentukan watak, iman dan tata nilai adalah keluarga asal (The family of Origin).

\section{Keluarga}

Keluarga merupakan lingkungan primer dalam membentuk kecerdasan moral anak. Sebelum anak menerima pengaruh dari teman sebaya dan guru di sekolah, ia sudah lebih dulu dibentuk ibu dan ayahnya, serta dipengaruhi saudara maupun pengasuhnya. Dengan kata lain, bagi anak, keluarga asal dianggap sangat berharga, dengan dinamika dan kondisi apa pun, jadi betapa berharganya keluarga dalam kehidupan ini. ${ }^{29}$ Dengan demikian keluarga adalah pokok pangkal proses pendidikan. Setiap keluarga adalah awal dari proses pengarahan yang memungkinkan tahapan pertumbuhan berikutnya. $^{30}$ Sudah merupakan pendapat umum bahwa sekitar 80-85\% dari watak dasar kita merupakan hasil belajar selama enam tahun pertama dalam kehidupannya. Sisanya terbentuk dan berkembang dalam perjalanan hidup berikutnya pada masa remaja, pemuda dan dewasa. Karakter yang kita pelajari dalam tahun-tahun berikutnya di bangun di atas pola-pola dasar kebiasaan yang sudah tertanam sebelumnya pada masa anak-anak, termasuk ke dalamnya nilai-nilai hidup, sikap mental dan pola pikir, disiplin, dan cara menghadapi krisis serta pola-pola komunikasi. Kebiasaan itu telah tersimpan dalam alam bawah sadar dan pra sadar kita. $^{31}$

\footnotetext{
${ }^{29}$ Ibid, 17.

${ }^{30}$ Warren Stanley Heath, Keluarga Kristen, (Bandung: Biji Sesawi, 2016), Cet.1, 37.

${ }^{31}$ BS. Sidjabat, membangun Pribadi Unggul, (Yogyakarta: ANDi, 2011), Cet.1, 5-6.
} 

Oleh karena itu pedidikan karakter sangat penting untuk diberikan kepada anak sejak dini, untuk bekal hidupnya dikemudian hari, dalam menghasilkan karakter yang mulia. Dalam pertumbuhan anak, ia belajar dan menyerap nilai hidup dan kebiasaan dari keluarga melalui pengamatan, peniruan, dan pengalaman, anak belajar banyak hal dari keluarga tempat ia bertumbuh. Membesarkan anak secara sehat pada dasarnya ialah tugas memenuhi kebutuhan anak itu sendiri, yang mencakup fisik, sosial, emosional, mental, dan spiritual. Dengan demikian orang tua patut memahami berbagai kebutuhan itu. Apa saja tugas perkembangan anak dan kebutuhannya sejak dilahirkan hingga usia 12 tahun. Dibawah ini adalah gambaran kebutuhan dan perkembangan anak dari bayi hingga 12 tahun yang penting untuk diketahui, sehingga orang tua menjadi bijak dalam menghadapi perkembangan anak dari dari periode lepas periode.

\begin{tabular}{|c|c|c|c|c|}
\hline Tahap & Periode & $\begin{array}{c}\text { Tugas } \\
\text { Perkembangan }\end{array}$ & $\begin{array}{c}\text { Hasil } \\
\text { Perkembangan }\end{array}$ & Keutamaan \\
\hline 1 & $\begin{array}{l}\text { Bayi } \\
(0-2 \text { th })\end{array}$ & $\begin{array}{l}\text { 1. Keterikatan Sosial } \\
\text { 2. Pematangan fungsi indra- } \\
\text { motorik } \\
\text { 3. Kecerdasan sensomotorik dan } \\
\text { kausalitas primitif } \\
\text { 4. Permanensi objek } \\
\text { 5. Perkembangan emosi }\end{array}$ & $\begin{array}{c}\text { Kepercayaan } \\
\text { dasar (Trust) } \\
\text { Versus } \\
\text { ketidakpercayaan } \\
\text { (Misterius) }\end{array}$ & $\begin{array}{c}\text { Harapan } \\
\text { (Hope) }\end{array}$ \\
\hline 2 & $\begin{array}{l}\text { Kanak- } \\
\text { kanak } \\
(2-4 \text { th })\end{array}$ & $\begin{array}{l}\text { 1. Perlunya daya gerak } \\
\text { 2. Permainan dan fantasi } \\
\text { 3. Pengembangan bahasa } \\
\text { 4. Pengendalian diri } \\
\text { (Self-control) }\end{array}$ & $\begin{array}{l}\text { Kemandirian } \\
\text { (autonomy) } \\
\text { versus rasa malu } \\
\text { dan Ragu-ragu } \\
\text { (Shame and } \\
\text { Doubt) }\end{array}$ & $\begin{array}{l}\text { Prakarsa/ } \\
\text { kehendak } \\
\text { (Will) }\end{array}$ \\
\hline 3 & $\begin{array}{l}\text { Pra } \\
\text { Sekolah } \\
\text { (4-6 th) }\end{array}$ & $\begin{array}{l}\text { 1. Identifikasi peran seks } \\
\text { 2. Perkembangan awal moral } \\
\text { 3. Bermain dalam kelompok } \\
\text { 4. Perkembangan harga diri }\end{array}$ & $\begin{array}{l}\text { Inisiatif } \\
\text { (Initiative) } \\
\text { versus rasa } \\
\text { bersalah } \\
\text { (Guilt) }\end{array}$ & $\begin{array}{l}\text { Tujuan } \\
\text { (Purpose) }\end{array}$ \\
\hline 4 & $\begin{array}{l}\text { Anak SD } \\
\text { (6-12 th) }\end{array}$ & $\begin{array}{l}\text { 1. Persahabatan (Friendship) } \\
\text { 2. Penilaian Diri (Self } \\
\text { evaluation) } \\
\text { 3. Pola pikir konkrit } \\
\text { (Concrete operational) } \\
\text { 4. Belajar ketrampilan (Skill } \\
\text { Learning) } \\
\text { 5. Bermain sebagai tim } \\
\text { (Team play) }\end{array}$ & $\begin{array}{l}\text { Ketekunan } \\
\text { (Industry) versus } \\
\text { rasa rendah diri } \\
\text { (Inferiority) }\end{array}$ & $\begin{array}{l}\text { Kemampuan } \\
\text { (Competence) }\end{array}$ \\
\hline
\end{tabular}



Tentu saja, yang terpenting dari semua kebutuhan di atas adalah perjumpaan anak dengan Yesus, inilah yang mendasari semua pemenuhan kebutuhan di atas. Inilah yang mendasari pendidikan karakter Kristen. Orang tua harus membawa anak sejak dini untuk beriman kepada Allah dan percaya kepada Yesus kristus, dengan demikian, maka Roh Kudus akan mengerjakan pembaharuan hidup dalam diri anak. Roh itu hadir mendampingi dan memampukan anak dalam pertumbuhan kepribadiannya. Tentu saja dengan bahasa yang dapat mereka mengerti, kemudian dibimbing untuk menyambut Yesus, mengaku percaya kepada Dia dan karya-Nya di salib, kehadiran Roh Allah membuat perubahan baru dalam diri anak. Akibatnya, mereka lebih mudah menerima nasehat, lebih gemar mendengar dan mempelajari Firman Tuhan, lebih rindu mengikuti pembinaan, lebih sensitif terhadap temannya dan lebih taat kepada orangtuanya. ${ }^{32}$ Jadi proses didikan kepada anak untuk hidup beriman harus dituntaskan sebelum anak itu menginjak usia remaja. ${ }^{33}$

Namun untuk mempersiapkan anak pada perjumpaan dengan Yesus, tentu saja kehidupan keluarga harus menjadi contoh bagi anak tersebut. Suasana yang penuh dengan cinta kasih, tetapi dalam disiplin adalah persiapan anak untuk percaya. Teladan orang tua sebagai pelaku Firman Allah dalam kehidupan rumah tangga sangat menolong juga. Lebih-lebih jika ayah-ibu dan sang anak berdoa serta membaca Alkitab bersama-sama setiap hari, akan mempercepat kesadaran rohani anak itu. Prinsip dasar penginjilan anak ialah menginjili mereka sedini mungkin. Sering, anak berusia tiga atau empat tahun sudah siap untuk percaya kepada Yesus sebagai Juruselamat pribadinya. Prinsip kedua ialah jika anak sudah percaya kepada Yesus, binalah anak itu untuk bertumbuh terus di dalam imannya. ${ }^{34}$

\section{Guru di Sekolah}

Para guru mempunyai tugas yang sangat penting dalam membina karakter anak-anak. Bimbingan yang baik oleh seorang guru dapat mengoreksi sebagian dampak kelalaian orangtua yang kurang bertanggung jawab. Kedudukan seorang guru yang sebenarnya ialah sebagai wakil/wali orangtua anak didik. Guru yang mewakili orangtua sepanjang puluhan jam setiap minggu, seyogyanya menunjang usaha mereka (orangtua) supaya kedua konteks pembinaan itu tidak menimbulkan kontradiksi di ranah pengertian anak. ${ }^{35}$

Tidak sedikit juga orang memandang bahwa tugas guru yang utama hanya menyampaikan pengetahuan kepada anak didiknya. Padahal sesungguhnya tugas guru disekolah lebih dari membangun kemampuan kognitif. Sepatutnya guru ikut membantu anak didiknya dalam pertumbuhan dimensi afektif dan kepribadian. Pembentukan watak atau karakter anak juga merupakan tugas dan panggilan di sekolah. Mendesaknya pendidikan watak dan nilai ini diperkuat oleh arah pendidikan agama Kristen (PAK) di sekolah pada masa kini. Sejak 2004, PAK di sekolah telah mengembangkan kurikulum berbasis kompetensi (KBK), Aktivitas PAK di sekolah tidak lagi memberi tekanan kepada pengajaran dogma sebagaimana terjadi selama ini khususnya berdasarkan kurikulum 1975, 1983 dan tahun 1993-4 yang lalu. Dewasa ini dan ke depan diharapkan bahwa PAK lebih menekankan penyadaran diri anak supaya memahami nilai hidup kristiani dan menghayati serta merefleksikan nilai itu dalam kehidupannya. Nilai hidup yang diajarkan itu bersumber dari pribadi Allah Tritunggal dan karya-

${ }^{32}$ BS. Sidjabat, Membesarkan Anak Dengan Kreatif, (Jogyakarta: ANDI, 2008), Cet.1, 8.

${ }^{33}$ Warren Stanley Heath, Keluarga Kristen, (Bandung: Biji Sesawi, 2016), Cet.1, 45.

\author{
${ }^{34}$ Ibid. 43. \\ ${ }^{35}$ Ibid. 47.
}


Nya, yang dipejari dari Alkitab. ${ }^{36}$ Jadi guru PAK di sekolah berfungsi sebagai pengajar iman, nilai hidup dan Karakter. Dilihat dari kaca mata Injil, cita-cita pendidikan ini selaras dengan apa yang pernah diajarkan dan diteladankan oleh Yesus Kristus, Sang Guru Agung. Yesus mengajari para murid untuk mengetahui rahasia kerajaan Allah dan kebenarannya; untuk merasakan betapa besar kasih dan kesetiaan Allah Bapa di surga; juga untuk mampu melakukan kebenaran itu sendiri dalam kehidupan sehari-hari dengan bertindak adil, benar, jujur dan kudus. ${ }^{37}$

Para ahli pendidikan menekankan bahwa anak didik mempunyai berbagai kebutuhan yang perlu mendapat pemenuhan secara arif, bijak dan benar. Kebutuhan anak yang dimaksud mencakup penghargaan, penerimaan, rasa aman, kasih dan penerimaan, serta kebutuhan rohani. Kalau seorang guru salah dalam memenuhinya, hasilnya membawa masalah pada diri anak dikemudian hari. Salah satu kebutuhan anak yang penting mendapat perhatian guru ialah konsep diri positif. Sebaliknya kebutuhan yang tidak terpenuhi melahirkan berbagai masalah termasuk perasaan kecewa, frustasi, bahkan penolakan. Pikiran negatif, perasaan buruk dan perilaku yang menyimpang (abnormal) dalam diri orang dapat terjadi karena kebutuhan yang dirasakan tidak atau belum terpenuhi. ${ }^{38}$

Belakangan ini di Amerika, upaya pengembangan nilai hidup atau karakter sangat gencar, melalui program-program formal, dan non Formal. Diusulkan bahwa sejak di sekolah dasar anak perlu dibekali dengan pendidikan nilai, karakter dan keterampilan hidup. Di sekolah dasar, anak dapat mempelajari karakter dasar berikut: Sikap dapat di percaya, menghormati; bertanggung jawab; adil; peduli; dan

\footnotetext{
${ }^{36}$ BS. Sidjabat, Membangun Pribadi Unggul, (Yogyakarta: ANDi, 2011) Cet.1, 25.

${ }^{37}$ Ibid.

${ }^{38}$ Ibid. 161
}

bermasyarakat. Keterampilan hidup yang diajarkan kepada anak usia Sekolah Dasar: Cara mengendalikan emosi; kreatif menyelesaikan konflik; mendengarkan orang lain; mengatasi sikap usil; mengatasi buruk sangka; bekerjasama; bertanggung jawab; mengatakan tidak dan ya; mengatasi kekecewaan; menghargai diri sendiri; meminta pertolongan teman; menjadi sahabat. Semua hal ini tentunya penting ditanggapi oleh para pendidik di sekolah. ${ }^{39}$ Keterlibatan staff pembina dan pengajar dalam membentuk komunitas yang bertanggung jawab dan berkomitment bagi pengembangan karakter sangat diperlukan; Pertama, harus menjadikan dirinya teladan moral yang dilihat oleh nara didik, agar mereka mempunyai tiruan. Kedua, bekerja sama di antara para pengajar untuk mendemontrasikan karakter yang sehat. Ketiga, kegiatan refleksi bersama semua pihak dalam komunitas sekolah sangat dibutuhkan untuk mengevaluasi sejauh mana pembentukan karakter telah berlangsung. ${ }^{40}$

\section{Gereja}

Pendidikan kristen pada dasarnya merupakan pendidikan moral atau karakter. Pendidikan moral itu berlangsung dalam komunitas (persekutuan) orang percaya. Komunitas bukan hanya wadah bertemu untuk beribadah tetapi "community as Educator." Gereja sebagai komunitas orang Kristen perlu mengambil peran dalam pendidikan watak, dalam konteks gereja, peran guru dibutuhkan. ${ }^{41}$ Seperti orang dewasa punya pergumulan, demikian juga anak-anak, bahkan remaja. Sebagaimana orang dewasa punya gaya yang unik dalam belajar serta bersosialisasi dengan orang lain, demikian juga anak-anak. Guru di

\footnotetext{
${ }^{39}$ BS. Sidjabat, Membesarkan Anak Dengan Kreatif, (Jogyakarta: ANDI, 2008), Cet.1, hal 265

${ }^{40}$ Ibid. 269

${ }^{41}$ Craig Dykstra, Vision and Charakter: A Christian Educator's Alternative to Kohlberg, (NeW York: Paulist Press, 1981), hal 124-125.
} 
gereja tidak bisa asal mengajar atau asal membelajarkan anak sama dengan orang dewasa. Singkatnya guru di gereja perlu memahami sungguh-sungguh anak-anak yang Allah percayakan untuk dilayani.

Untuk itu perjumpaan dengan Yesus dan relasi yang akrab dengan Allah merupakan kunci penting bagi seorang guru di gereja dalam menjalankan tanggung jawab pelayanannya. Keakraban tersebut akan terpancar dari dirinya menghasilkan sikap hidup yang berkenan di hadapan Allah serta menjadi berkat bagi anak-anak yang dididiknya. Selain itu pengenalan dan penerimaan terhadap diri sendiri dari sang guru pun merupakan hal yang tidak kalah penting. Setelah seorang guru mengenal siapa Allah dan dirinya sendiri, dia pun perlu mengenal bahkan menjalin relasi yang baik dengan anak-anak yang dibinanya. ${ }^{42}$

Guru memfasilitasi proses belajar, yaitu aktivitas sadar tujuan yang menjadi tempat peserta didik merasakan, berpikir, berdiskusi, membagikan pengalaman, memahami, menyelidiki, dan berpartisipasi. Lima langkah yang sepatutnya dilakukan guru dalam pembelajaran watak; Pertama, dengan sikap sensitif mengenali peserta didiknya, termasuk konteks kehidupan (tetangga, musuh-musuh, dan orang-orang asing) dan pergumulan (konflik) yang tengah dialaminya. Kedua, menyediakan sumber-sumber belajar dalam rangka menuntun peserta didik memahami pergumulannya. Sumber-sumber yang dimaksud termasuk pengajaran Alkitab. Ketiga, guru memberanikan peserta didik mengusulkan konsep "jalan keluar" cara menghadapi konflik atau pergumulan moral yang dihadapi. Kerjasama peserta didik dalam penyertaan guru amat penting dalam kegiatan. Guru dapat berperan mengajukan pertanyaan, melakukan klarifikasi, mendorong peserta menyelidiki sumber-

\footnotetext{
${ }^{42}$ Hani Rohayani, Kualitas Guru Sekolah Minggu, dalam Terarah Sungguh Berpijak Teguh; Kumpulam pemikiran Teologis dalam Rangka Ulang Tahun ke 40 Tiranus, (Bandung: STA Tiranus, 2006), Cet. 1, 339.
}

74 | Vol. 4 No. 2 (Desember 2020) sumber Alkitab lebih jauh dalam rangka menghadapi persoalan. Guru dan peserta didik dapat mengusulkan langkah-langkah praktis menghadapi pergumulannya.

Keempat, guru memberi kesempatan bagi peserta didik untuk bergumul dengan pemahaman yang sudah diperbincangkan. Dengan demikian, pemikiran awal yang sudah dibahas itu semakin mendalam. Melalui kesempatan ini peserta didik sadar bahwa langkah untuk menyelesaikan pergumulannya tidak perlu tergesa-gesa. Kelima, guru memotifasi peserta didik untuk melakukan hal yang dipelajarinya mulai dengan langkah kecil. Guru meyakinkan peserta didiknya bahwa dalam penerapan kebenaran itulah kasih karunia dan pertolongan Tuhan semakin nyata. Dalam langkah ini peran guru adalah sebagai pendengar, pendamping dan rekan dialog. Pendidikan moral dan karakter dapat dan perlu diikuti oleh warga jemaat secara menyeluruh, anak-anak, remaja dan dewasa. Dalam hal ini perlu memahami tugas perkembangan peserta didik demikian juga perbedaan tingkat usia dan pola berpikir. ${ }^{43}$

\section{KESIMPULAN}

Kesimpulan yang penulis peroleh dari paparan mengenai Pendidikan Karakter Kristen, adalah sebagai berikut:

Pertama, sudah saatnya PAK memperhatikan pendidikan yang dapat membentuk perilaku manusia bukan sekedar membekali manusia dengan pengetahuan dan informasi saja, terlebih tantangan di abad 21 ini semakin bersifat variatif, akumululatif, sistematis, dan masif, di antaranya menyangkut masalah moral, pengaruh pluralisme/relativisme, dan lainlain yang melibatkan segala golongan usia. Untuk itu penting dalam PAK, adanya pendidikan karakter Kristen, supaya nara didik berakar sehingga bertahan terhadap

\footnotetext{
${ }^{43}$ Craig Dykstra, Vision and Charakter: A Christian Educator's Alternative to Kohlberg, (NeW York: Paulist Press, 1981), hal 130-137.
} 
situasi dan kondisi disekitarnya. Oleh karena itu pendidikan karakter Kristen sangat penting.

Kedua, namun tentu saja pendidikan karakter Kristen, tidak dapat diberikan kepada nara didik yang belum mengalami perjumpaan dengan Yesus secara pibadi. Karena orang yang belum mengalami perjumpaan dengan Yesus secara pribadi kecenderungannya melakukan hal yang buruk, karena akibat dosa. Sehingga manusia mengalami kerusakan total dan ketidakmampuan total, maksudnya kerusakan total manusia akibat dosa tersebut menjangkau aspek pikiran, hati nurani, kehendak hati, emosinya dan keberadaannya secara menyeluruh sehingga menyebabkan ketidak mampuan total manusia untuk melakukan, menyatakan, atau memikirkan hal yang sungguh-sungguh diperkenan Allah. Ini menyebabkan manusia diluar Kristus susah diajar terlebih menghasilkan karakter yang mulia, karena manusia sudah mati secara rohani dan tidak ada yang membuatnya layak dihadapan Tuhan

Ketiga, Jadi pendidikan karakter yang tepat sebenarnya harus dimulai dengan perjumpaan pribadi seseorang dengan Yesus. Alkitab menyatakan bahwa ketika orang membuka dirinya bagi Yesus, mengaku percaya dengan sungguh (bdk.rm 10:9-10), Roh Yesus hadir dalam dirinya. Roh itulah yang kemudian mengerjakan tabiat baru. Akhlak mulia, yang berasal dari Kristus. Di dalam atau oleh karena Yesus sendirilah kehidupan orang percaya dapat berubah sehingga yang lama berlalu dan yang baru datang (bdk. 2 Kor 5:17). Jadi, bertumbuh dengan karakter yang mulia menjadi sangat mungkin terjadi dalam kehidupan orang Kristen.

Keempat, Dengan demikian, pendidikan dan pembelajaran karakter merupakan alat bantu, media atau sarana dalam pembentukan pribadi manusia. Agent dalam pendidikan karakter di antaranya keluarga, guru di sekolah, dan gereja. Dan para ahli psikologi dan pendidikan menyatakan bahwa lingkungan dan agen paling banyak mempengaruhi pembentukan watak, iman dan tata nilai adalah keluarga asal (The family of Origin).

Kelima, Oleh karena keluarga asal merupakan agent primer dalam pembentukan nara didik, maka keluarga asal harus memahami kebutuhan dan perkembangan anak, sejak dilahirkan hingga umur 12 tahun. Dan tuntaskanlah penginjilan kepada anak sebelum anak itu remaja, sehingga hal ini akan menjadi modal/bekal yang kuat bagi si anak tersebut dalam menyikapi tantangan kehidupan pada saat itu dan dikemudian hari, tentu saja pada pelaksanannya guru disekolah dan gereja harus saling mendukung. Sehingga nara didik menjadi garam dan terang dalam praktek hidupnya sehari-hari sebagaimana yang dikehendaki Tuhan Yesus Kristus (Mat 5:13-16).

\section{DAFTAR PUSTAKA}

Alouw A. Rudy, Konseling Intervensi Bagi Anak Korban Sexual Abuse, Dalam Menjadi Hamba Yang Setia, Cendikia, Dan Berhati Mulia; Sebuah Antologi, STA Tiranus (Bandung: 2016).

Anthony A. Hoekema, Diselamatkan Oleh Anugerah, Momentum (Jakarta:2010).

Dykstra Craig, Vision and Charakter: A Christian Educator's Alternative to Kohlberg, Paulist Press, (NewYork: 1981)

Faot Nimrod F, Spiritualitas Dan Postmodernitas Duet Atau Duel?, Dalam Jurnal Teologi Pengarah. STA Tiranus, (Bandung: 2010). 
Faot Nimrod F, Merintis Gereja Misioner Di Tengah Ancaman Penganiayaan, Dalam Setia Sebagai Pewarta Kabar Baik; Festschrift 70 Tahun Dr. Purnawan Tenibemas, STA Tiranus, (Bandung, 2017)

Gunawan Samuel T, Membangun dan Mengembangkan Karakter Kristen yang Kuat, Dalam Khotbah Ibadah Raya GBAP EL Shddai, Belum Diterbitkan, (Palangka Raya: 2013).

J.C Wofford, Kepemimpinan Kristen Yang Mengubahkan, ANDI, (Yokyakarta: 2001).

Lie Giok Tan, Pendidikan Kristen Menjawab Tantangan Abad ke -21; Suatu Pendekatan Reformatif, Dalam Menjadi Hamba Yang Setia, Cendikia, Dan Berhati Mulia; Sebuah Antologi, STA Tiranus, (Bandung: 2016).

Poerwadarminta W.J.S, Kamus Umum Bahasa Indonesia, Balai Pustaka, (Jakarta:1953).

Rohayani Hani, Kualitas Guru Sekolah Minggu, Dalam Terarah Sungguh Berpijak Teguh; Kumpulam pemikiran Teologis dalam Rangka Ulang Tahun ke 40 Tiranus, STA Tiranus, (Bandung: 2006).

Sidjabat B.S, Membesarkan Anak Dengan Kreatif, ANDI, (Yogyakarta: 2008).

Sidjabat B.S, Membangun Pribadi Ungggul, ANDI (Yogyakarta: 2011).

Sidjabat B.S, Jangan Lupakan Teladan Yesus, Sang Guru Agung, Dalam Jurnal Teologi Pengarah, STA Tiranus, (Bandung: 2010).

Soedarmo R, Ikhtisar Dogmatika, BPK Gunung Mulia, (Jakarta:1985).

Tenibemas Purnawan, Spiritualitas di Sekolah Teologi, Dalam Jurnal Teologi Pengarah, STA Tiranus (Bandung: 2010).

Tenibemas Purnawan, Andil Kita Dalam Misi Masa Kini, Dalam Pengarah Jurnal Teologi Kristen, STA Tiranus (Bandung: 2019).
Stephen Tong Stephen, Arsitek Jiwa II, Momentum, (Jakarta: 2010).

Warren Stanley Heath Warren, Keluarga Kristen, Biji Sesawi, (Bandung: 2016). 